\title{
How Child and Youth Care Students Think About and Practice Forgiveness: A Qualitative Course-Based Research Study
}

\author{
Michelle Derkson, Alyssa Bush, Karley Leverenz, Katrina Panchyshyn, and Gerard Bellfeuille
}

\section{ABSTRACT}

\begin{abstract}
At the core of child and youth care (CYC) practice is the ability to cultivate meaningful and positive relationships with children and youth. As CYC students we are taught from day one that knowing one's self is a pre-condition to building positive and meaningful relationship with others. As a result, we are educated to become more self-aware, a process that involves building our capacity to honestly recognize our beliefs, emotions, personality traits, values, biases, and motivations. Most importantly, we are taught to be forgiving because as human beings we are adept at hiding awkward or painful truths from ourselves. The aim of this course-based study is to contribute to the body of relational CYC knowledge by investigating the perceptions of CYC students' understanding and practice of the concept of forgiveness. The data were analyzed using a six-phased process of thematic analysis based on the work of Braun and Clark (2006). Four themes emerged from the thematic analysis: (a) freedom, (b) learning how, (c) forgiveness is a process, and (d) your road to forgiveness is your own.
\end{abstract}

Keywords: child and youth care, course-based research, forgiveness, qualitative

\section{INTRODUCTION}

At the core of child and youth care (CYC) practice is the ability to cultivate meaningful and positive relationships with children and youth (Bellefeuille, Ricks, \& Jamieson, 2012; Krueger, 1991; Ricks, 1989). The importance and significance of being self-aware is, therefore, an essential aspect of a CYC student's professional development. As CYC students we are taught from day one that knowing one's "self" is a pre-condition to knowing "others." We learn that self-awareness requires building one's capacity to honestly recognize beliefs, emotions, personality traits, values, biases, and motivations. Most importantly, we are taught to be forgiving because forgiveness is the cornerstone of any relationship.

\section{A. The Art of Forgiveness}

Similar to other virtues, forgiveness is an ancient ideal that has been studied and discussed for thousands of years, yet
Published Online: January 15, 2020

ISSN: $2736-4534$

DOI : $10.24018 /$ ejedu.2021.2.1.29

Michelle Derkson,

Bachelor of Child and Youth Care

Student, MacEwan University, Edmonton

Alberta, Canada

Alyssa Bush

Bachelor of Child and Youth Care

Student, MacEwan University, Edmonton

Alberta, Canada

Karley Leverenz

Bachelor of Child and Youth Care

Student, MacEwan University, Edmonton

Alberta, Canada

Katrina Panchyshyn

Bachelor of Child and Youth Care

Student, MacEwan University, Edmonton

Alberta, Canada

Gerard Bellfeuille

Professor, Bachelor of Child and Youth

Care Student, MacEwan University,

Edmonton Alberta, Canada

(bellefeuilleg@ macewan.ca)

*Corresponding Author there is no consensus in the literature, which spans various disciplines, regarding how to define the act of forgiveness (Denton \& Martin, 1998). There are, however, certain recurring characteristics that are commonly used to describe the concept of forgiveness. For example, Scobie and Scobie (1998) describe the act of forgiveness as a "conscious decision to set aside one's legitimate claim for retaliation or restitution for a damaging act committed by a significant other" (p. 382). For McCullough, Worthington, and Rachal (1997) forgiveness is explained as:

...the set of motivational changes whereby one becomes (a) decreasingly motivated to retaliate against an offending relationship partner; (b) decreasingly motivated to maintain estrangement from the offender; and (c) increasingly motivated by conciliation and goodwill for the offender, despite the offender's hurtful actions (pp. 321-322). 
Though forgiveness is often understood as a circumstantial response or as a learned skill, a variety of studies have concluded that it is also largely influenced by aspects of one's personality, which has been coined as trait forgiveness (Bartlett \& DeSteno, 2006; McCullough \& Hoyt, 2000). In the end, forgiveness is a personal process. As Desmond Tutu (2014), South Africa's former Anglican archbishop and a recipient of the Nobel Peace Prize, said, "We don't forgive to help the other person. We don't forgive for others. We forgive for ourselves." In other words, forgiveness is a positive act of self-interest.

\section{UNDERGRADUATE COURSE-BASED RESEARCH}

This section begins with a word about course-based research. The Bachelor of Child and Youth Care program at MacEwan University is continuously searching for new pedagogical approaches to foster critical thinking, reflection, and praxis as integral components of the overall student educational experience. As such, a course-based research approach, in contrast to the traditional didactic approach to research-methods instruction, offers fourth-year undergraduate students the opportunity to master introductory research skills by conceptualizing, designing, administering, and showcasing small low-risk research projects under the guidance and supervision of the course instructor-commonly, a professor with an extensive background in research and teaching.

The use of course-based research in higher education has increased substantially in recent years (Allyn, 2013; Bellefeuille, Ekdahl, Kent, \& Kluczny, 2014; Harrison, Dunbar, Ratmansky, Boyd, \& Lopatto, 2010). The benefits derived from a course-based approach to teaching research methods are significant for CYC students. First, there is value in providing students with authentic learning experiences that enhance the transfer of knowledge learned in traditional education practice. For example, former students have reported that their engagement in course-based research enabled them to deepen their scientific knowledge by adopting new methods of creative inquiry. Second, coursebased research offers students the opportunity to work with instructors in a mentoring relationship; one result is that a greater number of student's express interest in advancing to graduate studies. Third, results generated through coursebased research can sometimes be published in peer-reviewed journals and online open-access portals and thereby contribute to the discipline's knowledge base. The ethical approval required to permit students to conduct course-based research projects is granted to the course instructor by the university's research ethics board (REB). Student research groups are then required to complete an REB application form for each course-based research project undertaken in the class; each application is reviewed by the course instructor and an REB committee to ensure that the project is completed in compliance with the ethics review requirements of the university.

The focus of the course-based research project presented here is to explore how self-aware CYC students are about being forgiving to both themselves and others. More specifically, this study explores how CYC students define forgiveness, assesses their capacity to forgive themselves and others, and examines the reasons behind their choices to forgive or not.

\section{RESEARCH DESIGN}

Exploring the question of how CYC students at MacEwan University view forgiveness required a methodology that considered the nature of the phenomenon being studied. As Lincoln, Lynham, and Guba (2011) point out, it is imperative that researchers consider paradigm issues critical to their inquiry and not proceed without having a clear understanding of the paradigm that best informs their research question. Similarly, Crotty (1998) states that research designs should be based on the concepts of ontology (the way the researcher defines the nature of reality), epistemology (the process by which the researcher comes to know the nature of reality), and methodology (the framework that guides the research process, including strategies, methods and analysis). With the aim to gain broad insight rather than test a specific hypothesis, this coursed-based research project was undertaken using a qualitative rather than a quantitative approach.

\section{SAMPLING STRATEGY}

A non-probability, purposive sampling strategy was used to identify participants for this study. A basic principle of non-probability sampling techniques is that sampling is generally assumed to be selected purposefully to yield cases that are information rich (Cresswell, 2013). Purposive sampling is the specific technique of recruiting participants based on a set of criteria. According to Dudovskiy (2017), purposive sampling can be highly effective in exploring lived experiences that have to do with an intuitive approach. We drew our purposive sample from a group of undergraduate CYC students at MacEwan University.

\section{STATEMENT OF RESEARCH QUESTION}

The following research question guided the inquiry: How do CYC students at MacEwan University view forgiveness?

\section{DATA COLLECTION STRATEGY}

Data were collected using semi-structured, online focus groups facilitated by the videoconferencing platform Zoom. There is a wealth of literature on the benefits of remote datacollection methods (Chen \& Neo, 2019; Ferrante, 2016 et al.; Tuttas, 2015), which include greater flexibility in time and location, increasing convenience, efficiency, and costeffectiveness for both the researcher and participants (Cater, 2011; Deakin, \& Wakefield, 2014; Fielding, Lee, \& Blank, 2016). Semi-structured focus-groups fit well with our interpretive focus as they consist of a dialogue between researcher and participant, characterized by guided questions, probes, and comments (Denzin \& Lincoln, 2011; Kidd \& Parshall, 2000; Krueger \& Casey, 2000). 


\section{DATA ANALYSIS}

A crucial component of ensuring data integrity is the selection of an appropriate data analysis method (Creswell, 2013). Thus, Braun and Clark's (2006) six phase approach to data analysis was selected, as it aligns well with the interpretive research paradigm. The six phases include (1) familiarizing oneself with the data, (2) generating initial codes, (3) searching for themes, (4) reviewing themes, (5) defining and naming themes, and (6) producing the report. Braun and Clark (2006) explain that the aims of thematic analysis are to make sense of the data and provide an accurate account of what the data mean. They also point out that thematic analysis should not be undertaken as a linear process but rather a recursive, reflexive process of moving back and forth between phases.

\section{FINDINGS}

The thematic analysis resulted in the identification of the following four themes: (a) freedom, (b) learning how, (c) forgive is a process, and (d) forgiveness is a very personal process. Each is discussed below.

\section{A. Freedom}

Under the theme of freedom, several of the participants described the freedom of forgiveness as being relieved of a burden. For example, one participant referred to the act of forgiveness "as a weight off one's shoulders". Another participant used the term "relief." For a few other participants, to forgive meant, "creating a new chapter for yourself and others" and hitting a "restart button." For all of these participants, forgiveness was experienced as a liberating practice that not only enabled the one who had wronged them to be free from the past but also allowed the forgivers themselves to live more fully in the present, a key capacity of relational-centered practice.

\section{B. Learning How}

The theme of forgiveness as a learning process emerged strongly from the data. For example, one participant described forgiving as "something that takes practice." Others used words such as "forgiveness is a learned thing" and forgiveness is "learned from personal experience with others." The concept of forgiveness as a learned skill or developed personal capacity was not shared by all participants, which leads to the broader nature versus nurture debate.

\section{Forgiveness is a process}

Perhaps one of the most significant sub-themes within the concept of freedom is that it takes time, meaning that forgiveness is not an act but a process. Several of the participants were very clear that being ready to forgive is a key step in the forgiveness process. For example, participants' comments included the following: "you can't forgive unless you are ready," "forgiving is a deeper level then just saying sorry," "when one forgives two are healed," and forgiveness is like "walking along with the other person."

\section{Your Road to Forgiveness is Your Own}

The concept of the forgiveness process as a personal journey implies that there are many factors in play. While all of the participants experienced the four common themes, the forgiveness process was not the same for any two participants. The qualitative data analysis revealed that the forgiveness experience is a profound individual process that looks different for everyone. Some of the comments expressed by the participants included, "even though you forgive someone, the connection isn't the same," "it is the hardest thing to do in someone's life," and "not everyone is able to forgive."

\section{CONCLUSION}

The central purpose of this course-based study was to explore how CYC students view forgiveness as an important component of CYC practice. Both the findings of this coursebased study and the previous literature support the view that forgiveness is indeed a multi-faceted and complex process with individual differences. However, one qualitative coursebased study cannot adequately investigate how CYC understand, value, and intentionally practice forgiveness. The researchers thus recommend that this course-based study be replicated or that other aspects of forgiveness be explored to add to the growing body of knowledge of CYC relationalcentered practice competencies.

\section{REFERENCES}

Allyn, D. A. (2013). Course-based undergraduate research-It can be accomplished! Journal of Physical Education, Recreation \& Dance, 84(9), 32-36.

Bartlett, L., \& DeSento, D. (2006). Gratitude and prosocial behavior; helping when it costs you. Psychological Science, 17, 319-335

Bellefeuille, G., Ricks, F. \& Jamieson, D. (2012). Standing on the precipice: Inquiry into the creative potential of child and youth care practice, (2nd ed). Edmonton, AB: MacEwan Press: Edmonton.

Bellefeuille, G., Ekdahl, C., Kent, L., \& Kluczny, M. (2014). A course-based creative inquiry approach to teaching introductory research methods in Child and Youth Care undergraduate education. International Journal of Teaching and Education, 2(2), 1-9.

Braun, V., \& Clarke, V. (2006). Using thematic analysis in psychology. Qualitative Research in Psychology, 3(2), 77-101.

Cater, J. (2011). Skype: A cost effective method for qualitative research. Rehabilitation Counselors \& Educators Journal, 4(2), 10-17.

Chen, J., \& Neo, P. (2019). Texting the waters: An assessment of focus groups conducted via the WhatsApp smartphone messaging application. Methodological Innovations, 12(3), 1-10.

Creswell, J. W. (2013). Qualitative inquiry and research design: Choosing among five approaches (3rd, ed.). Thousand Oaks, CA: Sage Publications.

Crotty, M. (1998). The foundations of social research. meaning and perspective in the research process. Thousand Oaks, Calif: Sage Publications.

Deakin, H., \& Wakefield, K. (2014). Skype interviewing: Reflections of two $\mathrm{PhD}$ researchers. Qualitative Research, 14(5), 603-616.

Denton, R. T., \& Martin, M. W. (1998). Defining forgiveness: An empirical exploration of process and role. The American Journal of Family Therapy, 26(4), 281-292.

Denzin, N.K. and Lincoln Y.S. (eds) (2011) The SAGE handbook of qualitative research, (4th ed). Thousand Oaks: Sage.

Dudovskiy, J. (2017). Research methodology: Purposeful sampling. Retrieved from http://research-methodology.net/sampling-in-primarydata-collection/purposive-sampling/\#_ftnref1Education USA. (2018).

Ferrante, J. M., Friedman, A., Shaw, E. K., Howard, J., Cohen, D. J., \& Shahidi, L. (2016). Lessons learned designing and using an online discussion forum for care coordinators in primary care. Qualitative Health Research, 26(13), 1851-1861

Fielding, N., Lee, R., Blank, G. (2016). The Sage handbook of online research methods. London: Sage.

Harrison, M., Dunbar, D., Ratmansky, L., Boyd, K., \& Lopatto, D. (2010). Classroom-based science research at the introductory level: Changes in career choices and attitude. CBE Life Sciences Education, 10(3), 279 
286

Kidd, P.S., \& Parshall, M.B. (2000). Getting the focus and the group: Enhancing analytical rigor in focus group research. Qualitative Health Research, 10(3), 293-308.

Krueger, R.A., \& Casey, M.A. (2000). Focus groups: A practical guide for applied research, (3rd ed). Thousand Oaks, CA: Saga

Krueger, M., 1991. Central themes in child and youth care. Journal of Child and Youth Care, 5(1), 77-88.

Lincoln, Y. S., Lynham, \& Guba, E. G., (2011). Paradigmatic controversies, contradictions, and emerging confluences. In N.

K. Denzin \& Y. S. Lincoln (Eds.), Handbook of qualitative research (4th ed) (pp.99-128). Thousand Oaks, CA: Sage Publications

McCullough, M.E., \& Hoyt, W.T. (2002). Transgression-related motivational dispositions: Personality substrates of forgiveness and their links to the Big Five. Personality and Social Psychology Bulletin, 28, 1556-1573.

McCullough, M. E., Worthington, E. L., Jr., \& Rachal, K. C. (1997). Interpersonal forgiving in close relationships. Journal of Personality and Social Psychology, 73, 321-336.

Ricks, F. (1989) Self-awareness model for training and application. Journal of Child and Youth Care, 4(1), 33-41.

Scobie, E. D., \& Scobie, G. E. W. (1998). Damaging events: The perceived need for forgiveness. Journal for the Theory of Social Behaviour, $28,373-401$.

Tuttas, C. A. (2015). Lessons learned using web conference technology for online focus group interviews. Qualitative Health Research, 25(1), 122-133.

Tutu, D., \& Tutu, M. (2014). The book of forgiving: The fourfold path for healing ourselves and our world. San Francisco, Oak: HarperOne 